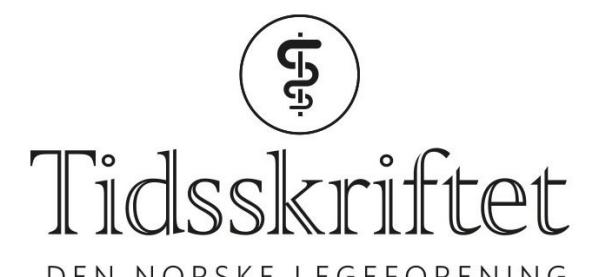

DEN NORSKE LEGEFORENING

\title{
CRISPR mindre presist enn først antatt
}

FRA ANDRE TIDSSKRIFTER

RUTH HALSNE

Tidsskriftet

CRISPR-metoden og andre genredigeringsverktøy prøves ut ved mange sykdommer. En ny studie tyder på at metoden kan gi genmutasjoner langt fra redigeringsstedet.

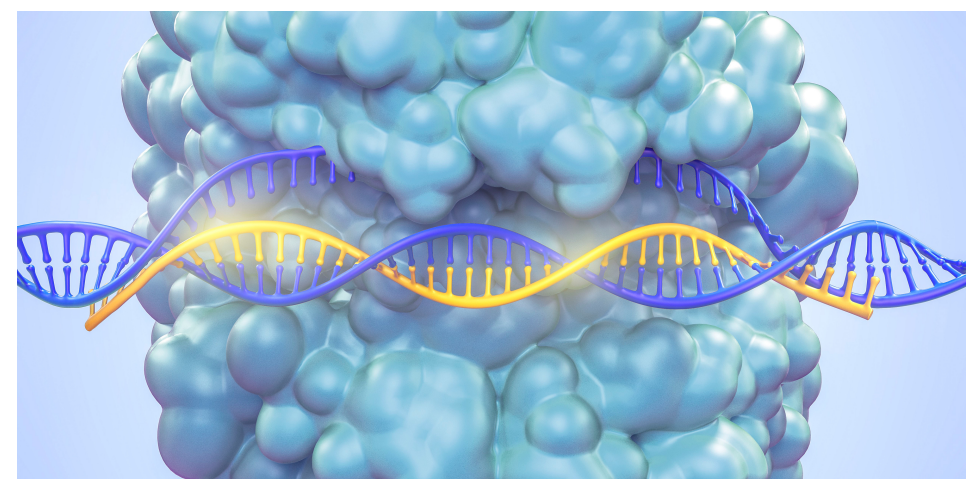

Illustrasjonsfoto: Science Photo Library / NTB scanpix

Det er knyttet store forventninger til genredigeringsmetoden CRISPR (Clustered Regularly Interspaced Short Palindromic Repeats). CRISPR kan benyttes i alle typer celler, og er billigere og mer effektiv enn mange andre metoder. I kliniske studier brukes CRISPRmetoden til å modifisere kreftpasienters immunceller for lettere å kunne gjenkjenne og bekjempe kreftceller. Ved undersøkelser av hvor nøyaktig DNA redigeres, er det oftest rapportert om små avvik i umiddelbar nærhet til bruddsonen.

I en studie publisert i tidsskriftet Nature Biotechnology undersøkte man hva som skjer i genloci fjernere fra bruddsonen når man benytter CRISPR-metoden (1). Embryoniske stamceller fra hannmus med allelisk diversitet for PIGA-locus koblet til kjønnskromosomene fikk innført Cas9 (CRISPR associated protein 9) og gRNA (guide-RNA) spesifikt for eksoner eller introner i PIGA-genet. PIGA-negative enkeltceller ble selektert, og en DNA-region med opptil 16 kilobaser ble hentet ut med nukleinsyreamplifisering før den ble sekvensert. Det ble påvist kompliserte, genomiske rearrangeringer med delesjoner langt fra bruddsonen, ofte i kombinasjon med insersjoner. Fors $\varnothing$ kene ble gjentatt med embryonale stamceller med et locus der begge allelene var tilgjengelige og i en human, differensiert cellelinje. I alle fors $\emptyset$ kene fant man store delesjoner av genetisk materiale og rearrangering av DNA etter bruk av CRISPR-metoden. Forfatterne konkluderer med at de genetiske endringene ikke er begrenset til redigeringsstedet. De ser for seg at når man 
redigerer celler i klinisk kontekst, kan det oppstå situasjoner der man introduserer mange mulig patogene mutasjoner som samlet kan føre til kreft.

- Denne studien er en av flere som avdekker utfordringer knyttet til nye genredigeringsverktøy, sier Arne Klungland, som er forskningsleder ved Avdeling for mikrobiologi ved Oslo universitetssykehus.

- CRISPR er en svært effektiv metode for å korrigere et gen, men den vil også kunne endre genomsekvensen et annet sted, sier Klungland. Han understreker likevel at metoden fortsatt er ny, og at det stadig gjøres fremskritt for å bedre presisjonen. Blant annet ved at enzymet som lager brudd i DNA-tråden, Casg, er forbedret slik at det kan lage enkelttrådbrudd i stedet for dobbelttrådbrudd. Det vil stimulere andre og mer presise reparasjonsmekanismer, som igjen fører til færre uønskede feil (2).

- CRISPR-metoden er allerede tatt i bruk i somatisk genterapi, og den har et stort potensial for en rekke applikasjoner innenfor genterapi, bl.a. ved Huntingtons sykdom, sier Klungland.

\section{LITTERATUR:}

1. Kosicki M, Tomberg K, Bradley A. Repair of double-strand breaks induced by CRISPR-Casg leads to large deletions and complex rearrangements. Nat Biotechnol 2018;36: 765-71. [PubMed][CrossRef]

2. Gao Y, Wu H, Wang Y et al. Single Cas9 nickase induced generation of NRAMP1 knockin cattle with reduced off-target effects. Genome Biol 2017; 18: 13. [PubMed][CrossRef]

Publisert: 21. januar 2019. Tidsskr Nor Legeforen. DOI: 10.4045/tidsskr.18.0850

(C) Tidsskrift for Den norske legeforening 2020. Lastet ned fra tidsskriftet.no 